doi:

\title{
Iskolázottsági helyzetkép - Nyíregyházán telepi körülmények között élők körében
}

\author{
Balogh Erzsébet
}

főiskolai tanársegéd, Debreceni Egyetem Egészségügyi Kar, Szociális és Társadalomtudományi Intézet, Szociális Munka Tanszék. Nyíregyháza, Sóstói út 2-4.

\section{INFO}

ABSTRACT

\section{Balogh Erzsébet \\ balogh.erzsebet@foh.unideb.hu}

\section{Keywords}

educational attainment, level of education, settlement conditions

\begin{abstract}
Situational picture of the educational attainment of people living in settlements in Nyíregyháza. In our study we examine the education of people living in two separate settlements in Nyíregyháza focussing on the type and level of completed school(s) and qualification, what they think of their future studies and getting a qualification so that similarities and differences between the two settlements can be compared. In the analysis, we present data gained in the Husar and Eastern settlements and alsocompare them with data on education from the Quality of Life Research 2018 in Nyiregyháza and the 2016 Micro Census Research by KSH. One-variable and two-variable methods were used to analyze data. Our results show that in terms of education people living in settlements lag far behind the town, county, regional and national data.
\end{abstract}

\section{Kulcs szavak}

iskolai végzettség, iskolázottság, telepi körülmények

\begin{abstract}
Absztrakt. Tanulmányunkban azt vizsgáljuk, hogy Nyíregyházán a telepi körülmények között élők milyen iskolai végzettséggel, szakképzéssel rendelkeznek, hogyan vélekednek a jövőbeni tanulásról, szakmai képesítés megszerzéséröl, összehasonlítva a két telep között lévő hasonlóságot, különbözőséget. Az elemzésénél a nyíregyházi Huszár lakótelepi és Keleti lakótelepi-, a Nyíregyháza Életminősége 2018 adatokat-, és a KSH Mikrocenzus 2016 iskolázottságra vonatkozó adatok kerülnek bemutatásra, összehasonlitásra. $\mathrm{Az}$ adatok kiértékeléséhez egy- és többváltozós elemzési technikákat alkalmaztunk. Az adatok elemzésével eredményeink azt mutatjuk, hogy a Huszár telepen és a Keleti lakótelepen élők nagymértékủ elmaradást mutatnak mind a városi, mind a megyei, mind a régió és mind az országos adatokhoz képest iskolázottság vonatkozásában.
\end{abstract}

Ez a tanulmány a TOP-6.9.1-16-NY1-2017-00001 azonosító számú

"Közösen a kiútért" című projekt támogatásával készült. 


\section{Bevezetés}

A cigányság helyzete annyiban javult Magyarországon a rendszerváltozás óta, hogy helyzetüknek számtalan eleme feltárásra került. A hazai oktatás rendszerében többségben sikertelenek a roma a tanulók, kevésbé tudják kiaknázni a kötelező, oktatás által kínált lehetőségeket (Polónyi, 2002).

Kemény István és kutatótársai 1971-ben és 1993-ban a roma lakosság két százalékát, 2003-ban egy százalékát vizsgálták kutatásukban. Az első és a második vizsgálat közben eltelt időszakban annyi változás történt, hogy a roma fiatalok többsége $(77,7 \%)$ elvégezte az általános iskola nyolc osztályát. Az elvégzett nyolc osztály azért nem mindenkinél jelentett igazán elvégzett nyolc osztályt, a roma gyerekek nagy része nem tizennégy, vagy tizenöt éves korában szerezte meg az alapfokú iskolai végzettséget, hanem esetenként jóval későbbi életkorban. Az életkor növekedése nem állt egyenes arányban a tudás megszerzésével, minél idősebben fejezték be általános iskolai tanulmányukat, annál kevésbé jelent meg a tényleges tudás a bizonyítvány mögött. Az ezt követő években növekedett a továbbtanuló roma gyerekek száma (Kemény, 2009). A kilencvenes évek közepétől lassú emelkedés volt megfigyelhető abban, hogy a roma gyerekek az általános iskola befejezését követően középfokú oktatási intézményben kezdték meg tanulmányaikat, de a tanulmányokat megkezdő gyerekek kétharmada már az első évben be is fejezte azt (Liskó, 2002). A roma tanulók lemorzsolódásának csökkentése érdekében már a 2000-es évek elején is fogalmazódtak meg javaslatok (lásd erről Fónai és Filepné, 2001).

Egy teljes középiskolai kohorszot képező, reprezentatív, országos mintán a hazai roma tanulók középfokú iskolai pályájáról, valamint az azt követő felsőfokú tanulmányi esélyeikről Hajdú, Kertesi és Kézdi számolt be 2014-ben. Vizsgálatukban rámutattak, hogy messze elmarad a roma lakosság iskolázottsági szintje a nem roma lakosokétól. Jelentős mértékü felzárkózást mértek az általános iskola sikeres befejezésében és a középfokú továbbtanulásban, de a társadalom átlagához képest tovább növekvő leszakadást tapasztaltak mind az érettségi megszerzésének esélyében, mind a felsőfokú tanulmányokban való részvételben (Hajdu és mtsai, 2014).

Kevés írás jelent meg mindezidáig, melyek a lakóhelyi hátrányokkal hatásával foglalkoznak. Feltételezhető, hogy a roma tanulók iskolai lemaradásában nagy szerepe van annak a körülménynek, hogy nagy hányaduk az ország válságrégióiban, vagy hátrányos helyzetü településein lakik. Tanulmányunk ebből a szempontból igyekszik ezt pótolni, annak ellenére, hogy maga a település - Nyíregyháza - nem hátrányos helyzetü, ugyanakkor nem mondható ez el a szegregátumaiban lakókról. (A mintavételi alapadatokat lásd (Takács, Huszti, 2019), az itt élők lakáskörülményeiről lásd bővebben ebben a kötetben Szoboszlai (2019) írását.)

Hajdu és szerzőtársai (2014) nem foglalkoztak kutatásukban a lakóhelyi hátrányok hatásával. Úgy vélték, hogy önmagában ez a tényező nem játszik jelentős szerepet a társadalmi hátrányok kialakulásában. Azt találták, hogy az etnikai csoportok összehasonlításában ugyanazon a településen a roma és nem roma fiatalokra korlátozva a vizsgálatot, az eredetileg meglévő különbségek túlnyomó része megmaradt, melynek okát abban látták, hogy hazánkban viszonylag egyenletesen oszlanak meg területileg a középfokú oktatási intézmények. 
A foglalkoztatottság és iskolai végzettség közötti szoros összefüggését többek között Fónai és Filepné (2001); Polónyi (2002); Kemény (2009) Hajdu és mtsai (2014) tanulmányai vizsgálják, ebben a kötetben R. Fedor (2019) tárja fel a szegregátumban élők foglalkoztatási helyzetképét.

Az iskolai sikeresség kulcsfontosságú meghatározója a tanulási motiváció (Nagy, 2000). Ahogy arra Fejes (2005) is rámutatott, számos tényező akadályozhatja a roma tanulók tanulási motívumainak kialakulását az iskolán kívüli szociális közegben. Éppen ezért nagyon fontos, hogy a roma tanulók motivációját több irányból, a gyermek valamint a szülök, család és közösség oldaláról kell megközelíteni. A középfokú oktatási intézményekben meglévő nagymértékü különbségek a roma és nem roma tanulók között nagy részben összefüggésben vannak az általános iskolában megszerzendő alapkészségek nagyfokú hiányosságaival, aminek okai egészen a kisgyermekkorig is visszanyúlnak. Mivel az iskolai lemorzsolódások okai leginkább kisgyermek- és kisiskolás korban keletkeznek, a leghatékonyabban úgy tudjuk azt megelőzni, hogy ezekben az életkorokban kiemelt figyelmet fordítunk a felhalmozódott lemaradásokra.

\section{Befejezett tanulmányok, a megszerzett legmaga- sabb iskolai végzettség}

A KSH mikrocenzus időpontjában 2016-ban Magyarországon a megkérdezettek legnagyobb arányban érettségivel rendelkeztek, az arány $28 \%$-os volt. A befejezett iskolai vonatkozásában egyenlő arány mutatkozott a felsőfokú végzettség és a szakiskolai/szakmunkás végzettség között. Mindkét kategóriában 18\%-os arány volt kimutatható, azaz a népesség 18\%-a rendelkezett a megkérdezés időpontjában felsőfokú végzettséggel, valamilyen diplomával és $18 \%$ volt az aránya azoknak is, akik szakiskolai és/vagy szakmunkás végzettséggel rendelkeztek. Alapfokú, általános iskolai végzettséggel a mintába kerültek 20\%-a rendelkezett. Azoknak az aránya, akiknek nem sikerült megszereznie az alapfokú, általános iskolai végzettséget, a legalacsonyabb 17\%, de körükben megtalálhatóak voltak azok is, akik még nem tanköteles korúak, illetve azok is, akik a kérdezés időpontjában még általános iskolai tanulmányokat folytattak (KSH, 2016).

Nyíregyházán, a telepi körülmények között élők iskolai végzettségre vonatkozó adataiból ettől sokkal kedvezőtlenebb kép rajzolódik ki, mely az 1. ábrán látható.

Ahogy az 1. ábrán jól látható Nyíregyházán a telepi körülmények között élők leginkább alapfokú iskolai, 8 általános iskolai végzettséggel rendelkeznek, ebben nincs eltérés a két lakótelep között. Mint ahogy nincs jelentős különbség a többi kategóriában sem. Jelentősebb még azok aránya, akik szakiskolai és/vagy szakmunkás képzőben szerezték képesítésüket, és azok aránya is, akik nem szerezték meg az alapfokú iskolai végzettséget sem. Érettségivel is záródó középfokú végzettek és a felsőfokú végzettséget szerzők aránya nagyon alacsony mindkét almintában. Az ábra alapján levonhatjuk azt a következtetést, hogy az amúgy is alacsony iskolai végzettséggel rendelkezö, telepi körülmények között élök, alacsonyabban iskolázottak a Keleti lakótelepen. A Keleti lakótelepen élők körében kissé nagyobb arányban jelenik meg 
mind a 8 általános iskolai végzettség, mind a befejezetlen 8 általános iskolai végzettség, mint a Huszár lakótelepen. Körükben kisebb mértékü azok száma is, akik valamilyen szakiskolai, vagy szakmunkás végzettséget szereztek. Az adatok azt mutatják, hogy a Keleti lakótelepen élők nem is jelennek meg további iskolai végzettség kategóriában, az itt élők a legalsó három (kevesebb, mint 8 általános, 8 általános, szakiskolai/szakmunkás képesítés) iskolai végzettséggel rendelkeznek. Az e feletti iskolai végzettség megjelenése nem számottevő a Huszár lakótelepen sem, az itt élök között is igen alacsony azok aránya, akik érettségivel, vagy attól magasabb iskolai végzettséggel rendelkeznek.

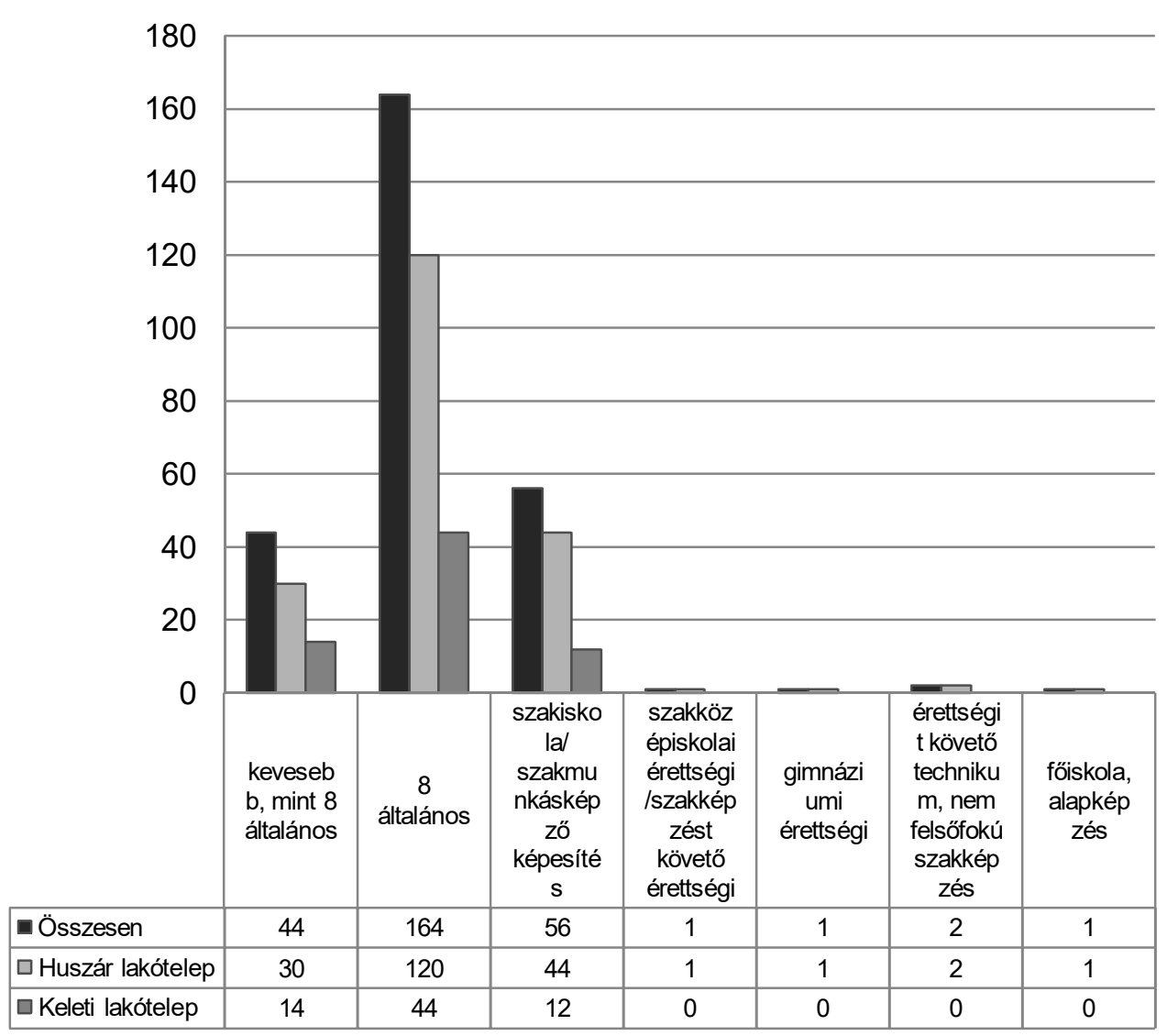

Forrás: Telepi kutatás, 2019

1. ábra Iskolai végzettség telepi körülmények között élők körében, Nyíregyházán N=269 (fö)

Ez valamennyire összhangban áll a Tárki életpálya felmérés adataival, hiszen az általuk vizsgált két évtized alatt a roma fiatalok alapfokú iskoláztatásában jelentős mértékủ növekedést mértek, az általános iskolai lemorzsolódásban minimális értéket mutattak ki (Hajdu és mtsai, 2014). A két szegregátumban élök nagyobb része is elvégezte az általános iskolát, igaz ugyan, hogy nem jelentős mértékben, de megjelennek a középfokú végzettséget szerzők is, mindkét lakótelepen. 
A következő, 2 ábrán összehasonlítjuk a telepi kutatás adatait a Nyíregyháza Életminősége 2018 és a KSH Mikrocenzus 2016 adataival.

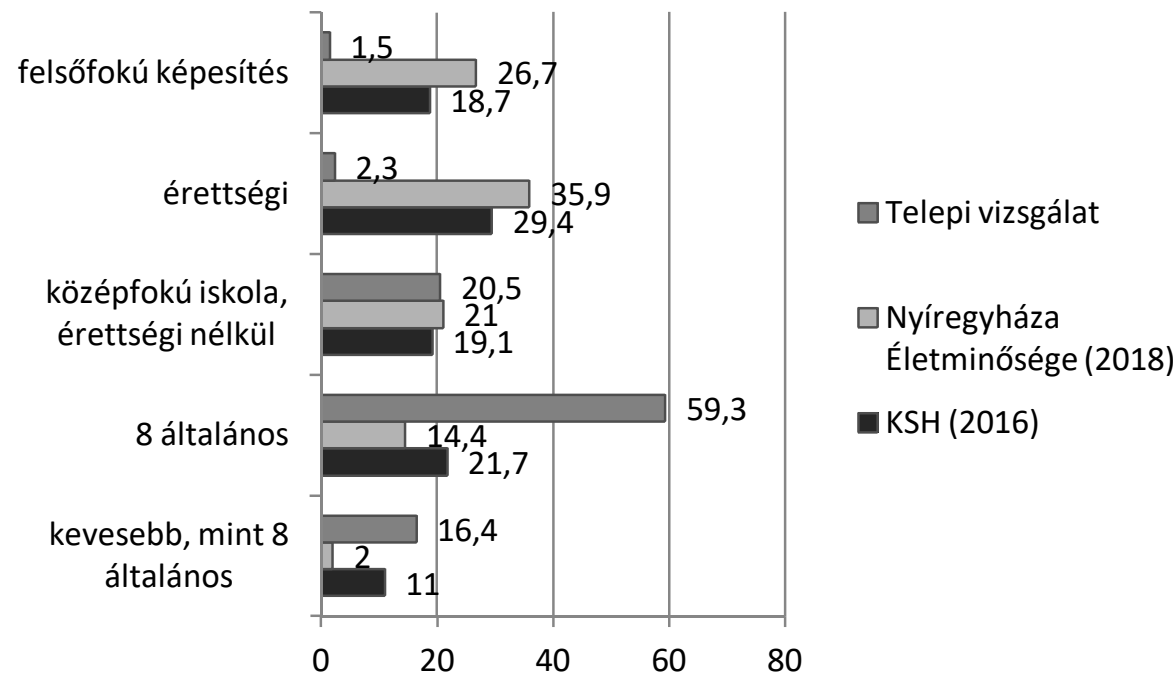

Forrás: Telepi kutatás 2019, Nyíregyháza Életminösége 2018, KSH Mikrocenzus 2016

\section{2. ábra Legmagasabb iskolai végzettség (\%)}

A 2. ábrán az adatokat összehasonlítva látványos a Nyíregyházán telepi körülmények között élők $(\mathrm{N}=268)$ iskolai végzettségének nagyfokú lemaradása mind az országos, mind a városi adatokhoz képest. Jól látható, hogy Nyíregyháza város lakossága magasabb iskolai végzettséggel rendelkezik, mint az országos mintába bekerültek. Ennek fényében még inkább erőteljesebben rajzolódik ki a telepen élők igen alacsony fokú iskolai végzettsége. Az adatok összevetéséből kitünik, hogy a másik két vizsgálat adataihoz képest igen magas a telepen élök között azok aránya, akik megszerezték az általános iskolai végzettséget, vagyis feltételezhetjük, hogy rendelkeznek azokkal az alapvető készségekkel, mint például írás, olvasás, számolás, melyekre ráépíthető a magasabb iskolai végzettség megszerzése, vagy akár egy szakma megszerzése is.

Az elmúlt évtizedekben a nők iskolai végzettségének emelkedése meghaladta a férfiak iskolai végzettségének emelkedését. Mindennek ellenére többen vannak azok a nők, akik alacsonyan iskolázottak, mint a férfiak. Összefügghet ez a korösszetétellel, hiszen a nők kora meghaladja a férfiak korát, és az idősek körében gyakrabban fordul elő az alacsony iskolai végzettség. A férfiak 30\%-a, a nők 36\%-a rendelkezett legfeljebb alapfokú, 8 általános iskolai végzettséggel 2016-ban. Az érettségi nélküli szakiskolai vagy szakmunkás képzőben szerzett képesítés esetében továbbra is jelentős a férfiak aránya a nőkéhez viszonyítva. A magasabb iskolai végzettség felé haladva a nők és férfiak aránya megfordul. Az érettségizett nők aránya elöször 1980ban haladta meg az érettségizett férfiak arányát. 2016-ban a nők 35\%-a, a férfiak $31 \%$-a rendelkezett érettségi bizonyítvánnyal. A nők előnye igaz a diplomások körében is. Míg az 1960-as évekig a férfi felsőfokú végzettek aránya 80-90\%-os volt, 
2016-ra a nők szereztek előnyt ezen a területen. A felsőfokú végzettséggel rendelkezők több mint fele - 56\% - nő volt (KSH, 2016).

A továbbiakban az iskolai végzettség nemek közötti megoszlását vizsgáltuk, melyet a 3. 4. és 5. ábrán mutatunk be.

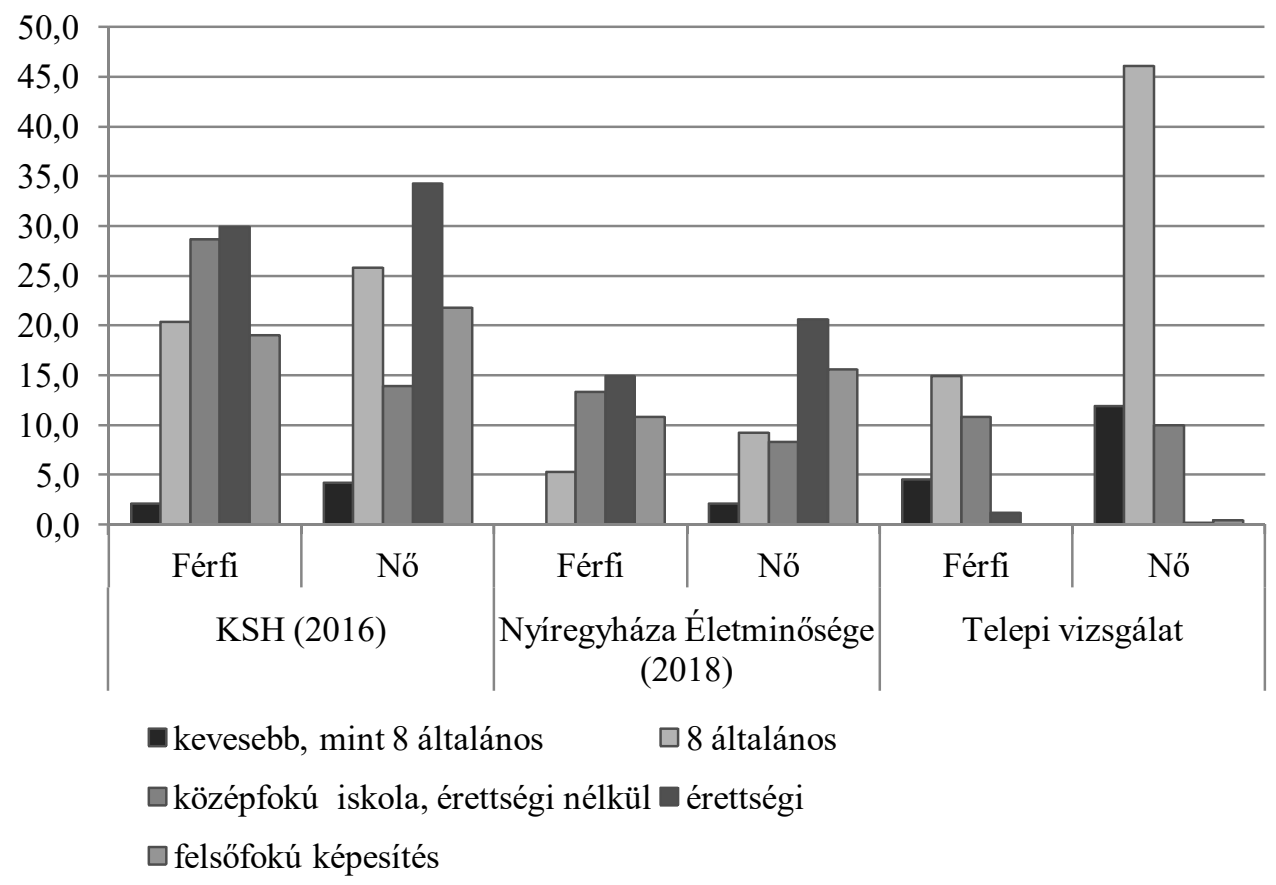

Forrás: Telepi kutatás 2019, Nyíregyháza Életminősége 2018, KSH Mikrocenzus 2016

3. ábra Iskolai végzettség nemek megoszlásában (\%)

Az előzőekben leírtakat támasztja alá a 3. ábra. A telepi vizsgálat és a Nyíregyháza Életminősége vizsgálat adatai is azt mutatják, hogy a legalacsonyabban iskolázottak között magasabb a nők aránya a férfiakéhoz képest. Többen vannak azok a nők, akiknek kevesebb, mint 8 általános iskolai végzettsége, vagy legfeljebb 8 általános iskolai végzettsége van, mint a férfiak. Az érettségi nélküli középfokú végzettek körében magasabb a férfiak aránya mindhárom vizsgálat adatai szerint. Az érettségi és az a feletti iskolai végzettek nők előnye a férfiakéhoz képest jól látható mind a KSH által mért, mind a Nyíregyháza Életminősége adatai szerint is. A telepi körülmények között élők körében inkább nem jellemző, hogy érettségivel, vagy felsőfokú végzettséggel rendelkeznek, de az igaz, hogy a telepi körülmények között élök között csak nők szereztek felsőfokú képesítést.

Minimális eltérést mutatnak az adatok az elöbbiekhez képest, ha megnézzük az iskolai végzettséget a megyeszékhelyek, az Észak Magyarországi Régió és Szabolcs-Szatmár-Bereg megye vonatkozásában, melyet a 4. ábra mutat. 


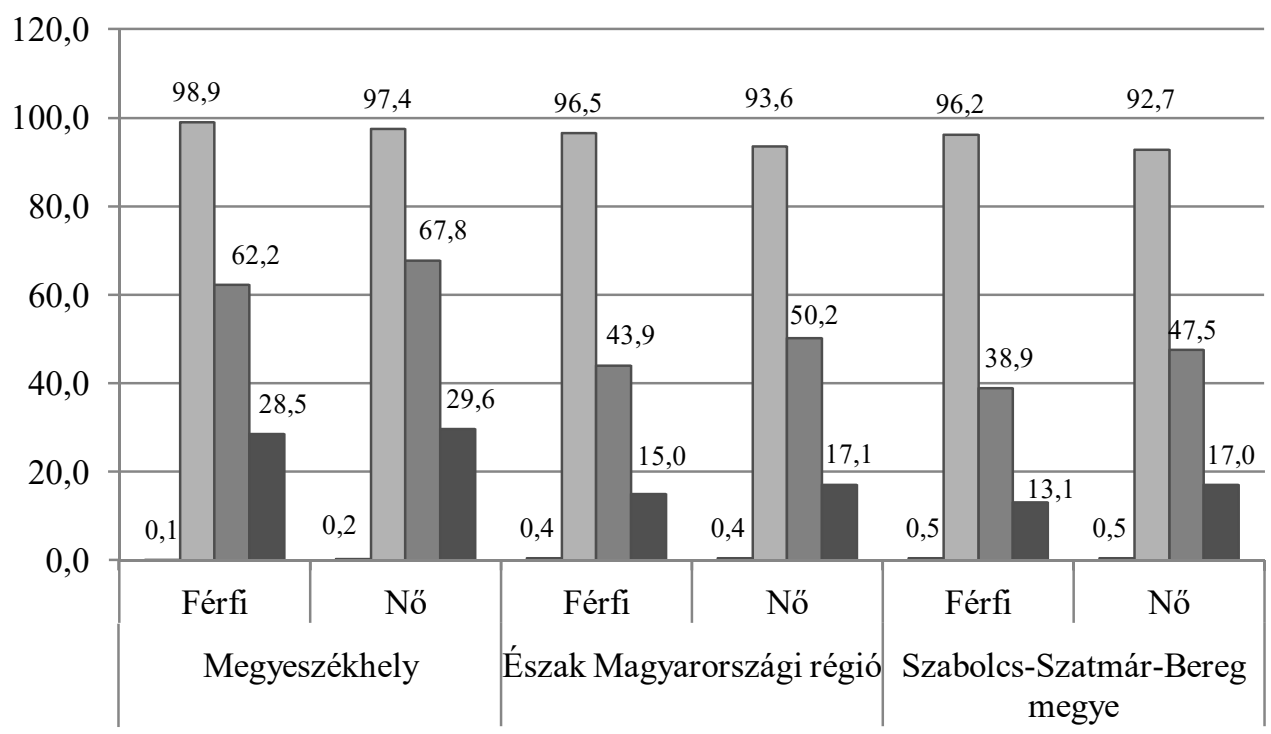

घevesebb, mint 8 általános $\square 8$ általános $\square$ érettségi $\square$ felsőfokú végzettség

Forrás: KSH Mikrocenzus 2016

4. ábra Iskolai végzettség nemek szerint városi rang, régió, megye szerint (\%)

A kevesebb, mint 8 általános iskolai végzettséggel rendelkező nők és férfiak aránya közel megegyezik megyeszékhelyi, régiós és megyei szinten is. Az alapfokú, 8 általános iskolai végzettek körében több a férfi, mint a nö. Az ettől magasabb iskolai végzettségnél viszont magasabb a nők aránya, mint a férfiaké. Az érettségi bizonyítvánnyal és a felsőfokú végzettséggel rendelkezők körében magasabb a nők aránya, mint a férfiaké, megyeszékhelyi, régiós és megyei szinten is.

$\mathrm{Az}$ 5. ábrán a telepi körülmények között élők iskolai végzettsége látható nemenként bontásban, százalékos megoszlásban. Ami jól látható, hogy a telepi körülmények között élők iskolai végzettsége leginkább a kevesebb, mint 8 általános iskolai osztályra, a 8 általános iskolai osztályra és a szakiskola/szakmunkásképző képesítésre korlátozódik. Mindkét lakótelepen magasabb azon nők aránya akik, befejezetlen vagy befejezett 8 általános iskolai végzettséggel rendelkeznek. A szakiskola/szakmunkás képző képesítéssel rendelkező férfiak mind a Huszár lakótelepen $(33,3 \%)$, mind a Keleti lakótelepen (37,5\%) többen vannak, mint a nök (Huszár $1 .: 17,3 \%$, Keleti 1.:6,5\%). Ettől magasabb iskolai végzettséggel rendelkezők csak a Huszár lakótelepen élnek. Ezen a lakótelepen szakközépiskolai érettségivel/szakképzést követő érettségivel és gimnáziumi érettségivel csak férfiak $(1,7 \%)$ rendelkeznek. Minimális előny látszik az érettségit követő technikum, nem felsőfokú képzés területén a férfiak javára, felsőfokú végzettséggel viszont kizárólag nők rendelkeznek a Huszár lakótelepen. 


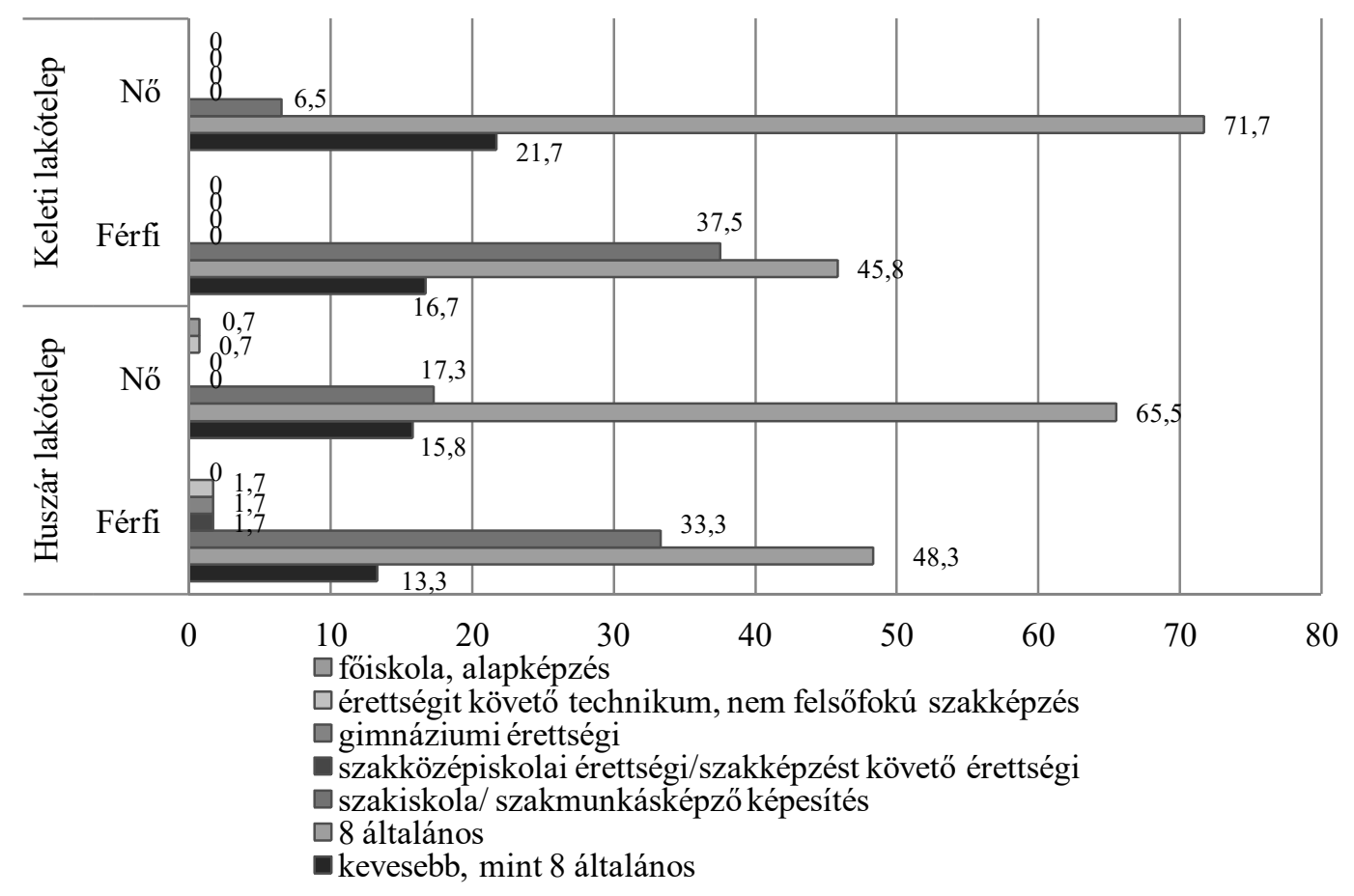

Forrás: Telepi kutatás 2019

5. ábra Iskolai végzettség nemek szerinti megoszlása telepi körülmények között élők körében (Huszár lakótelep $\mathrm{N}=199$; Keleti lakótelep $\mathrm{N}=70$; \%)

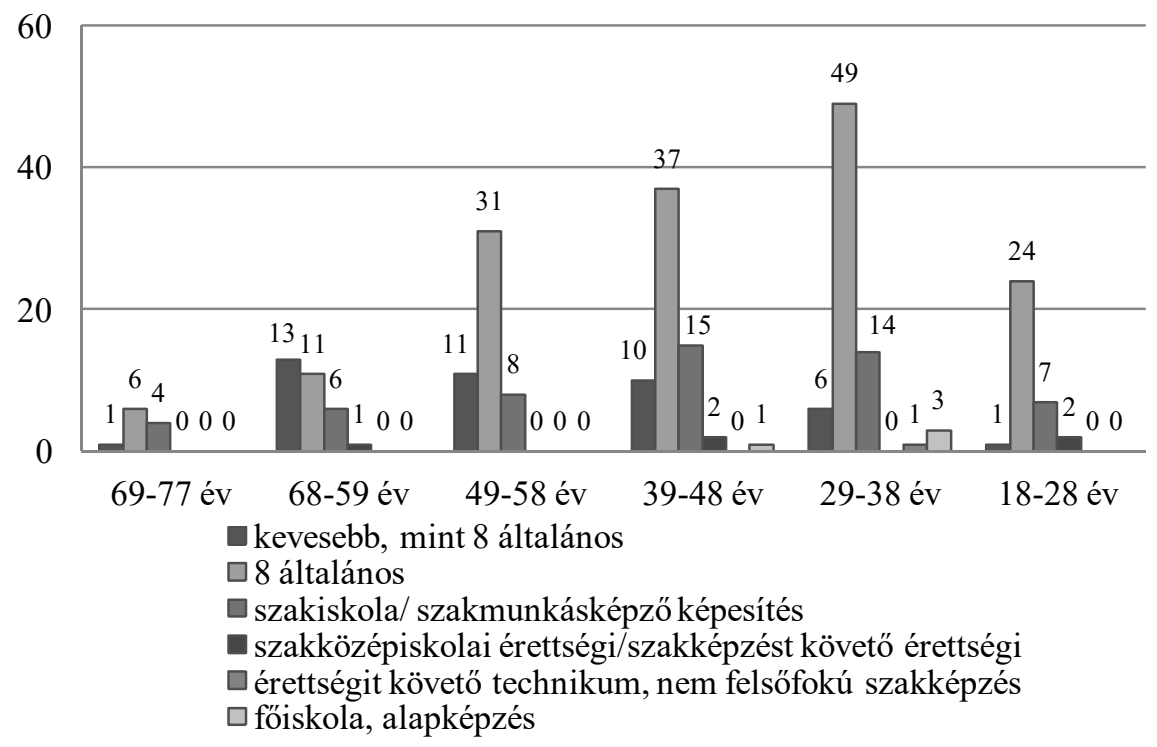

Forrás: Telepi kutatás 2019

6. ábra Iskolai végzettség telepi körülmények között életkori megoszlásban N=264 (fö) 
A 6. ábrán a Nyíregyházán megkérdezett telepszerü körülmények között élők iskolai végzettsége látható korcsoportonkénti bontásban. A kevesebb, mint 8 általános iskolai végzettséggel rendelkezők valamennyi korcsoportban jelen vannak. A 8 általános iskolai osztályt elvégzettek a 68-59 év közöttiek kivételével valamennyi korcsoportban a legtöbben vannak. Szakiskolai/szakmunkás képesítéssel leginkább a 38-48 év közötti korosztály rendelkezik, de a többi korcsoportban is jelen vannak. Az életkor elöre haladásával az egyre alacsonyabb iskolai végzettség jellemzi a telepi körülmények között élőket. Érettségivel és az a feletti végzettséggel a 18-39 korosztály rendelkezik, igen alacsony arányban. Ez az ábra is jól mutatja, hogy valamennyi korosztályban inkább az alacsonyabb iskolai végzettséggel rendelkeznek a telepeken élők.

Azok a vizsgálatban résztvevők, akik nem fejezték be a 8 általános iskolai osztályt az okok között családi okokat és anyagi okokat neveztek meg a befejezett tanulás okaként.

Liskó (2002) kutatásában a családi okok között említi, hogy a roma gyerekeket nem eléggé motiválja családjuk a továbbtanulásra, tovább gyengíti további tanulásukat a korai felnőtté válás és a korai szexuális érdeklődés, hiányoznak a pozitív minták a környezetükből, a továbbtanulás jelentős kiadásokat eredményez a családban, amit nem tudnak fedezni. A roma gyerekek szocializációjával bővebben lásd Forray és Hegedűs (1987; 1998), R. Fedor és Balogh (2016) írásait, a lakótelepen élők jövedelmi helyzetével ebben a kötetben Fábián Takács (2019) foglalkozik.

A megkérdezettek közel $80 \%$-a 14 és 18 éves korában fejezte be tanulmányait. Azok közül, akik 14 és 18 éves korukban befejezték tanulmányaikat, legtöbben 16 éves korukban, a jelenlég érvényben lévő tankötelezettségi kor után nem folytatták a tanulmányaikat.

A lemorzsolódás egyik igen jelentős összetevője lehet a roma tanulókat sújtó társadalmi elszigeteltség. Kevés az oktatási intézményben jól teljesítő fiatalokhoz köthető szoros kortárs kapcsolatuk (Hajdu és mtsai, 2014). A nyíregyházi szegregátumokban élők kapcsolataival lásd ebben a kötetben Huszti (2019) tanulmányát.

\section{Tanulással kapcsolatos elképzelések, jövőkép}

\begin{tabular}{|l|c|}
\hline Tanulmányok & \% \\
\hline $\begin{array}{l}\text { a tanulmányait sikeresen befejezte, ugyanakkor elkép- } \\
\text { zelhető, hogy a későbbiekben tanulni fog még }\end{array}$ & 61 \\
\hline a tanulmányait véglegesen és sikeresen befejezte & 100 \\
\hline $\begin{array}{l}\text { a tanulmányait félbehagyta, de elképzelhető, hogy } \\
\text { folytatni fogja }\end{array}$ & 39 \\
\hline $\begin{array}{l}\text { a tanulmányait félbehagyta de nem fogja/nem kívánja } \\
\text { folytatni }\end{array}$ & 48 \\
\hline
\end{tabular}

Forrás: Telepi kutatás 2019

1. sz. táblázat Mi igaz Önre? Az igen válaszok száma N=248 
A válaszadók kicsivel több, mint fele gondolta úgy a megkérdezés pillanatában, hogy a tanulmányait véglegesen és sikeresen befejezte, vagy a tanulmányait félbehagyta, de nem fogja/nem kívánja azt folytatni, ahogy látható az az 1 számú táblázatban. A telepi körülmények között élők valamennyivel kevesebb, mint fele gondolja viszont úgy, hogy elképzelhető, hogy a jövőben folytatni fogja a már befejezett, vagy félbehagyott tanulmányait. Legtöbben másik szakmát szereznének, ha folytatnák tanulmányaikat, de a tanulmányaikat elképzelhetően folytatók nem zárkóznak el az érettségi megszerzésétől sem. Az ettől magasabb iskolai végzettség megszerzése nem szerepel a telepi körülmények között élők tanulási tervei között.

\begin{tabular}{|l|c|}
\hline Tanulmányok és jó munkahely & $\mathbf{\%}$ \\
\hline egyáltalán nem ért egyet & 6,6 \\
\hline nem ért egyet & 12,2 \\
\hline részben egyet ért & 26,2 \\
\hline egyet ért & 32,8 \\
\hline teljes mértékben egyet ért & 19,6 \\
\hline
\end{tabular}

Forrás: Telepi kutatás 2019

2. sz. táblázat Minél többet tanulok/minél magasabb az iskolai végzettségem annál nagyobb esélyem van arra, hogy jó munkahelyem legyen $\mathrm{N}=264$ (\%)

Az 2. számú táblázat alapján elmondható, hogy az alacsony iskolai végzettséggel rendelkező válaszadó telepi körülmények között élök nagyobb részben egyetértenek azzal az állítással, hogyha minél többet tanulok/minél magasabb az iskolai végzettségem annál nagyobb esélyem van arra, hogy jó munkahelyem legyen. Ami jó kiindulási alapot képez a munkaerő-piaci elhelyezkedést minél nagyobb mértékben elösegítő képzések szervezésére a Huszár és a Keleti lakótelepen. A megkérdezetteknek csak 19,3\%-a utasítja el teljes mértékben ezt az állítást.

Hasonló helyzetképet mutat a 3. számú táblázat is.

\begin{tabular}{|l|c|}
\hline Tanulmányok és siker & $\mathbf{\%}$ \\
\hline egyáltalán nem ért egyet & 4,1 \\
\hline nem ért egyet & 12,5 \\
\hline részben egyet ért & 35,4 \\
\hline egyet ért & 29,9 \\
\hline teljes mértékben egyet ért & 15,9 \\
\hline
\end{tabular}

Forrás: Telepi kutatás 2019

3. sz. táblázat Minden ember, aki sokat tanul, sikeres lehet $\mathrm{N}=265(\%)$

A 3. számú táblázatban jól látható, hogy a telepi körülmények között élö, alacsony iskolai végzettséggel rendelkező válaszadók úgy gondolják, hogy sikeres csak az lehet, aki sokat tanul. Ezt az állítást csupán a válaszadók 16,6 \%-a utasítja el teljes mértékben. 


\begin{tabular}{|l|c|}
\hline Tanulás és pozitív változás & $\mathbf{\%}$ \\
\hline egyáltalán nem ért egyet & 5,2 \\
\hline nem ért egyet & 9,2 \\
\hline részben egyet ért & 35,8 \\
\hline egyet ért & 32,1 \\
\hline teljes mértékben egyet ért & 15,9 \\
\hline
\end{tabular}

Forrás: Telepi kutatás 2019

4. sz. táblázat Tanulással tudok elérni pozitív változást az életemben $\mathrm{N}=266(\%)$

A 4. számú táblázat adatai tovább erősíti azt a képet, hogy az alacsony iskolai végzettséggel rendelkező telepi körülmények között élök teljesen tisztában vannak azzal, hogy ahhoz, hogy erősödjön munkaerö-piaci helyzetük, sikeres legyen életpályájuk, életkörülményeikben pozitív változás következzen be, megfelelő iskolai végzettséggel kell rendelkezniük. Azzal az állítással, hogy Tanulással tudok elérni pozitív változást az életemben a válaszadók 83,8\%-a inkább egyetért. Az állítást teljes mértékben csak 14,4 \%-a utasítja el a válaszadóknak.

\begin{tabular}{|l|c|}
\hline Tanulmányok - nem hoz előrelépést & $\mathbf{\%}$ \\
\hline egyáltalán nem ért egyet & 24,0 \\
\hline nem ért egyet & 31,0 \\
\hline részben egyet ért & 29,2 \\
\hline egyet ért & 8,1 \\
\hline teljes mértékben egyet ért & 5,9 \\
\hline
\end{tabular}

Forrás: Telepi kutatás 2019

5. sz. táblázat Tanulni nem érdemes, azzal nem jutok előbbre az életben $\mathrm{N}=266$ (\%)

Az 5. számú táblázat adatai tovább erősítik az előzőleg leírt tendenciákat. Az alacsony iskolai végzettséggel rendelkező telepszerü körülmények között élő válaszadók nagyobb részben (84,2 \%) inkább elutasítják azt az állítást, hogy Tanulni nem érdemes, azzal nem jutok előbbre az életben. Inkább egyet ért ezzel az állítással a válaszadók $14 \%$-a

\begin{tabular}{|l|c|}
\hline Tanulmányok és lakóhely & $\mathbf{\%}$ \\
\hline egyáltalán nem ért egyet & 9,6 \\
\hline nem ért egyet & 24,4 \\
\hline részben egyet ért & 22,5 \\
\hline egyet ért & 14,4 \\
\hline teljes mértékben egyet ért & 27,3 \\
\hline
\end{tabular}

Forrás: Telepi kutatás 2019

6. sz. táblázat Minek tanuljak, ha megtudják hol lakom úgysem engem vesznek fel a munkára $\mathrm{N}=266(\%)$

A tanulmány elején megemlítésre került, hogy az iskolai végzettség nagymértékben hatással van többek között az életkörülményekre, lakhatási körülményekre is. Az iskolázottsági fok emelkedésével pozitívan emelkednek azok a hatások, amelyek 
befolyásolják az egyén életkörülményeit. A megfelelő iskolai végzettség és a megfelelő lakhatási körülmények pozitív hatással lehetnek az egyén munkaerő-piaci helyzetére is. Így gondolják ezt a Huszár és a Keleti lakótelepen élők is. Azzal az állítással, hogy Minek tanuljak, ha megtudják hol lakom úgysem engem vesznek fel a munkára inkább egyetértenek (64,2\%) a két lakótelepen élők. A megkérdezett válaszadók $34 \%$-a véli úgy a megkérdezés pillanatában, hogy lakhatási körülményeik nincsenek befolyással sem a tanulásukra, sem a munkaerö-piaci helyzetükre. Ezekre a kérdésekre adott válaszok igen polarizáltak, ezért megnéztük, hogy a „,Minek tanuljak, ha megtudják hol lakom úgysem engem vesznek fel a munkára” kérdés és a 2-5 táblázatban megjelenített kérdésekre/állításokra adott válaszok között találunk-e szignifikáns összefüggéseket. Elemzésünkben vizsgáltuk a korrelációs együtthatót és számoltunk Cramer-féle V mutatót is. Elemzésünk azt mutatta, hogy szignifikáns, de gyenge kapcsolat van valamennyi kérdés/állítás között.

\section{Összefoglalás}

Végezetül összegezzük kutatásunk főbb megállapításit. Tanulmányunkban Nyíregyházán a telepi körülmények között élők iskolai végzettségét, szakképzettségét, jövőbeni tanulásról, képzésről, szakmai képesítés megszerzéséről való elképzelésüket tártuk fel, összehasonlítva a két telep között lévő hasonlóságot, különbözőséget.

Elsőként a Huszár lakótelepen és a Keleti lakótelepen élők által megszerzett legmagasabb iskolai végzettséget vizsgáltuk. Az adatok azt mutatják, hogy az amúgy is alacsony iskolai végzettséggel rendelkező, telepi körülmények között élők, alacsonyabban iskolázottak a Keleti lakótelepen. A Keleti lakótelepen többen élnek azok, akik 8 általános iskolai végzettséggel, és befejezetlen 8 általános iskolai végzettséggel rendelkeznek. Körükben kisebb mértékü azok száma is, akik valamilyen szakiskolai, vagy szakmunkás végzettséget szereztek. A Keleti lakótelepen élők nem rendelkeznek kevesebb, mint 8 általános, 8 általános, szakiskolai/szakmunkás képesítés feletti iskolai végzettséggel. Az e feletti iskolai végzettség megjelenése nem számottevő a Huszár lakótelepen sem, az itt élők között is igen alacsony azok aránya, akik érettségivel, vagy attól magasabb iskolai végzettséggel rendelkeznek.

Következő vizsgálódásunk arra irányult, hogy összevetettük a telepi körülmények között élők iskolai végzettségét jellemző adatokat a település adataival. Nyíregyháza Életminősége 2018 adataival összehasonlítva eredményünk azt mutatja, hogy eröteljesen rajzolódik ki a telepen élők igen alacsony fokú iskolai végzettsége, a városi lakossághoz képest. Az azonban elmondható, hogy igen magas a telepen élők között azok aránya, akik megszerezték az általános iskolai végzettséget, vagyis rendelkeznek azokkal az alapvető készségekkel, mint például írás, olvasás, számolás, melyekre ráépíthető a magasabb iskolai végzettség megszerzése, vagy akár egy szakma megszerzése is.

Ezt követően a nemek tekintetében vizsgáltuk meg az iskolai végzettségre vonatkozó adatainkat. A telepi vizsgálat és a Nyíregyháza Életminősége 2018 vizsgálat adatai is azt mutatják, hogy a legalacsonyabban iskolázottak között magasabb a nők aránya a férfiakéhoz képest. Többen vannak azok a nők, akiknek kevesebb, mint 8 
általános iskolai végzettsége, vagy legfeljebb 8 általános iskolai végzettsége van, mint a férfiak. Az érettségi nélküli középfokú végzettek körében magasabb a férfiak aránya a vizsgálatok adatai szerint. Az érettségi és az a feletti iskolai végzettek nők előnye a férfiakéhoz képest jól látható mind a KSH által mért, mind a Nyíregyháza Életminősége adatai szerint is. A telepi körülmények között élők körében inkább nem jellemző, hogy érettségivel, vagy felsőfokú végzettséggel rendelkeznek, de az igaz, hogy a telepi körülmények között élők között csak nök szereztek felsőfokú képesítést.

A kevesebb, mint 8 általános iskolai végzettséggel rendelkező nők és férfiak aránya közel megegyezik megyeszékhelyi, régiós és megyei szinten is. Az alapfokú, 8 általános iskolai végzettek körében több a férfi, mint a nő. Az ettől magasabb iskolai végzettségnél viszont magasabb a nők aránya, mint a férfiaké. Az érettségi bizonyítvánnyal és a felsőfokú végzettséggel rendelkezők körében magasabb a nők aránya, mint a férfiaké, megyeszékhelyi, régiós és megyei szinten is. A telepi körülmények között élök iskolai végzettsége leginkább a kevesebb, mint 8 általános iskolai osztályra, a 8 általános iskolai osztályra és a szakiskola/szakmunkásképző képesítésre korlátozódik. Mindkét lakótelepen magasabb azon nők aránya akik, befejezetlen vagy befejezett 8 általános iskolai végzettséggel rendelkeznek. A szakiskola/szakmunkás képző képesítéssel rendelkező férfiak mind a Huszár lakótelepen, mind a Keleti lakótelepen többen vannak, mint a nők Ettől magasabb iskolai végzettséggel rendelkezők csak a Huszár lakótelepen élnek. A telepi körülmények között élő nők alacsonyabb iskolai végzettségének oka között megjelenhetnek a roma lakosság szokásai, hagyományai, tradíciói, de erre nem tért ki vizsgálatunk, ez további mélyebb kutatást igényel.

A telepi körülmények között élők, valamennyi korcsoportjában jelen vannak azok, akik kevesebb, mint 8 általános iskolai végzettséget szereztek meg. A Huszár lakótelepen és a Keleti lakótelepen élők iskolázottságának korcsoport szerint vizsgálata szerint valamennyi korcsoportban azok vannak a legtöbben, akik elvégezték a 8 általános iskolai osztályt. Szakiskolai/szakmunkás képesítéssel leginkább a 38-48 év közötti korosztály rendelkezik.

Azok a válaszadók, akik nem fejezték be a 8 általános iskolai osztályt, a tanulmányaik befejezésének okaként jellemzően családi okokat és anyagi okokat neveztek meg. A megkérdezettek leginkább 14 és 18 éves korukban fejezték be tanulmányaikat. Közülük is legtöbben 16 éves korukban, a jelenlég érvényben lévő tankötelezettségi kor után nem folytatták a tanulmányaikat.

Azok a telepi körülmények között élő válaszadók, akik nem zárkóznak el attól, hogy a jövőben folytassák a már befejezett, vagy félbehagyott tanulmányaikat, legtöbben másik szakmát szereznének, de nem zárkóznak el az érettségi megszerzésétől sem.

Az alacsony iskolai végzettség ellenére a telepi körülmények között élök nem utasítják el teljesen a további tanulás lehetőségét, a jelenlegi helyzetükből való kimozdulásra érzékelik, hogy a megfelelő iskolai végzettség megszerzése lehet az egyik út. Nagyobb részben egyetértenek azzal az állítással, hogyha minél többet tanulok/minél magasabb az iskolai végzettségem annál nagyobb esélyem van arra, hogy jó munkahelyem legyen. Ami jó kiindulási alapot képez a munkaerő-piaci elhelyezkedést minél nagyobb mértékben elősegítő képzések szervezésére a Huszár és a Keleti lakótelepen is. Úgy vélik, hogy sikeres csak az lehet, aki sokat tanul, érzékelik azt, hogy ahhoz, hogy erősödjön munkaerö-piaci helyzetük, sikeres legyen 
életpályájuk, életkörülményeikben pozitív változás következzen be, megfelelő iskolai végzettséggel kell rendelkezniük. Érzékelhető továbbá, hogy a Huszár lakótelepen és a Keleti lakótelepen élők is úgy vélik, hogy lakhatási körülményeik kissé hátrányosan befolyásolja tanulásukat, és munkaerő-piaci helyzetüket.

$\mathrm{Az}$ eredmények azt mutatják, hogy megfelelő tanulási motiválással/motiváltsággal és a lakhatási körülmények javításával a Huszár lakótelepen és a Keleti lakótelepen élök iskolai végzettsége pozitív irányú elmozdulást hozhat.

\section{Felhasznált irodalom}

1. Fábián G., Takács P. (2019): Jövedelmi viszonyok. Acta Medicina et Sociologica Vol 10. No.29. 45-54.

2. Fejes J. B. (2005): Roma tanulók motivációját befolyásoló tényezők. Iskolakultúra 2005/11:.3-13.

3. Fónai M., Filepné Nagy É. (2001): A roma tanulók helyzete a közoktatásban Szabolcs-Szatmár-Bereg megyében. Educatio 1. szám Oktatás - Politika - Kutatás: 169-177.

4. Forray R. K., Hegedüs T. A. (1987): Tanulmányok a cigányság beilleszkedéséről. Országos Pedagógiai Intézet, Budapest.

5. Forray R. K., Hegedüs T. A. (1998): Cigány gyermekek szocializációja, AULA, Budapest.

6. Hajdu T., Kertesi G., Kézdi G. (2014): Roma fiatalok a középiskolában. Beszámoló a Tárki Életpálya-felvételének 2006 és 2012 közötti hullámaiból. Budapest Munkagazdasági füzetek BWP 7. pp. 265-302.

7. Huszti É. (2019): Társas kapcsolatok a szegregátumban. Acta Medicina et Sociologica Vol 10. No.29. 115-130.

8. Kemény I. (2009): A romák/cigányok és az iskola. In.: Kállai E., Kovács L. (szerk): Megismerés és elfogadás. Pedagógiai kihívások és roma közösségek a 21. század iskolájában. Nyitott Könyvmúhely, Budapest. 193-215.

9. KSH (2016). Mikrocenzus. 4. Iskolázottsági adatok http://www.ksh.hu/mikrocenzus2016/kotet_4_iskolazottsagi_adatok Látogatva: 2019. április

10. Liskó I. (2002): A cigány tanulók oktatási esélyei. Educatio 1. szám Mérlegen 1990-2002.: 49-62.

11. Nagy J. (2000): XXI. század és nevelés. Osiris Kiadó, Budapest.

12. Polónyi I. (2002): A cigány népesség demográfiai, iskolázottsági és foglalkoztatási helyzete - s az abból adódó oktatáspolitikai következtetések. Iskolakultúra könyvek 13. A cigányság társadalomismerete. Pécs pp. 133-151.

13. R. Fedor A., Balogh E. (2016): A cigány gyerekek szocializációja a szakirodalom tükrében. In: Kósa Zs. (szerk.) Helyzetkép a magyarországi romákról. Debreceni Egyetemi Kiadó, Debrecen. 28-36.

14. R. Fedor A., Balla P. (2019): Foglakoztatási helyzetkép a telepi körülmények között élő nyíregyházi romák körében. Acta Medicina et Sociologica Vol 10. No.29: 32-44. 
15. Szoboszlai K. (2019): Lakhatási helyzetkép. Acta Medicina et Sociologica Vol 10. No.29: 19-31.

16. Takács P., Huszti É. (2019): A nyíregyházi Huszár- és Keleti lakótelepi vizsgálatok - a kutatás módszertana és a minta néhány alapvető jellemzője. Acta Medicina et Sociologica Vol 10. No.29: 8-18. 